June 2015

\title{
PRICE ELASTICITIES OF FOOD DEMAND: COMPENSATED VS UNCOMPENSATED*
}

\author{
by \\ Kenneth W Clements \\ Business School \\ The University of Western Australia \\ and \\ Jiawei Si \\ Business School \\ The University of Western Australia
}

\begin{abstract}
Cornelsen et al. (2014) and Green et al. (2013) provide a comprehensive review/summary of a large number of recent estimates of the price elasticity of food consumption using a meta-regression approach. In this letter, we introduce a way of removing the income effect from these elasticities to recover the compensated elasticities. Although the income effect is small, the compensated elasticities vary by income group. Both types of elasticity should possibly be considered when assessing the impact of policy changes on food consumption.
\end{abstract}

\footnotetext{
Note: We thank Rosemary Green and Laura Cornelsen for sending us the data underlying Cornelsen et al. (2014) and for responding to our enquiries. We also thank the World Bank for sending us unpublished data. Lastly, we would like to thank two anonymous referees whose comments significantly improved the letter. This research was supported in part by the ARC and BHP Billiton.

" Correspondence to: Kenneth Clements, Economics (UWA Business School), The University of Western Australia (M251), 35 Stirling Highway, Crawley WA 6009, Australia. Phone: +61 864882898 E-mail: Ken.Clements@uwa.edu.au.
} 


\section{Introduction}

In two recent papers, Cornelsen et al. (2014) and Green et al. (2013) summarise 78 studies of food demand carried out since 1990 using a meta-regression approach. These two papers represent a major contribution in synthesising such a large body of research by providing centre-of-gravity uncompensated price elasticities for seven food items in three groups of countries, distinguished by income per capita. ${ }^{1}$ These elasticities answer the question, what is the impact of a price rise on consumption when consumers' money income is held constant? But for some purposes it is useful to know the response when consumers' real income remains unchanged. ${ }^{2}$ In this letter, we show how compensated elasticities can be recovered from the uncompensated elasticities reported by Cornelsen et al. (2014).

\section{Consumption Theory}

Let $\mathrm{p}_{\mathrm{i}}$ and $\mathrm{q}_{\mathrm{i}}$ be the price and quantity demand of $\operatorname{good} \mathrm{i}(\mathrm{i}=1, \ldots, \mathrm{n})$, so that $\mathrm{M}=\Sigma_{\mathrm{i}=1}^{\mathrm{n}} \mathrm{p}_{\mathrm{i}} \mathrm{q}_{\mathrm{i}}$ is total expenditure ("income" for short) and $\mathrm{w}_{\mathrm{i}}=\mathrm{p}_{\mathrm{i}} \mathrm{q}_{\mathrm{i}} / \mathrm{M}$ is the $\mathrm{i}^{\text {th }}$ budget share. The Slutsky equation links the compensated and uncompensated elasticities as follows:

$$
\eta_{\mathrm{ij}}^{*}=\eta_{\mathrm{ij}}+\mathrm{w}_{\mathrm{j}} \eta_{\mathrm{i}}
$$

Here,

$$
\eta_{\mathrm{ij}}^{*}=\left.\frac{\partial\left(\log \mathrm{q}_{\mathrm{i}}\right)}{\partial\left(\log \mathrm{p}_{\mathrm{j}}\right)}\right|_{\substack{\text { utility } \\ \text { constant }}}
$$

is the $(\mathrm{i}, \mathrm{j})^{\text {th }}$ compensated price elasticity (the substitution effect), $\eta_{\mathrm{ij}}$ the uncompensated elasticity, $w_{j} \eta_{i}$ the income effect with $\eta_{i}=\partial\left(\log q_{i}\right) / \partial(\log M)$ the income elasticity of good i. In the spirit of "want-independence" of Frisch (1959, propositions 56 and 56a, p. 185), we make the simplifying assumption that the marginal utility of consumption of each good is

\footnotetext{
${ }^{1}$ Cornelsen et al. (2014) draw upon the estimated own-price elasticities from Green et al. (2013), which is based on 136 studies over the same time period.

${ }^{2}$ For example, suppose a tax is imposed on consumption of good $j$ and the revenue from the tax is redistributed back to consumers as a lump sum. This keeps real income unchanged and the impact of a one-percent rise in the price of $j$ on the consumption of $i$ is given by the $(i, j)^{\text {th }}$ compensated elasticity. But note that lump-sum transfers mean there can be no distributional effects. That is, with lump-sum transfers, intensive consumers of good $\mathrm{j}$ do not receive full compensation for the price rise, so there is an income transfer from intensive to nonintensive consumers. The overall effect of this depends on differences across groups in marginal propensities to spend. Note also the case in which tax revenues are earmarked for health programs: If these programs are valued at their cost by consumers, then, effectively, real income remains unchanged and the compensated elasticity is the relevant concept to use. If the programs are wasteful, however, real income falls and in the extreme when the programs are valueless, the uncompensated elasticity is to be used. For intermediate cases, a weighted average of the two elasticities can be used.
} 
independent of the consumption of the others ("preference independence"). Under preference independence, the consumer's utility function is (some increasing function of) the sum of $n$ sub-utility functions, one for each good: $u\left(q_{1}, \ldots, q_{n}\right)=\sum_{i=1}^{n} u_{i}\left(q_{i}\right)$, with $u_{i}(\cdot)$ the $i^{\text {th }}$ subutility function that depends only on the consumption of good $i$.

Given the prices, the consumer chooses the consumption basket to maximise utility, $\sum_{\mathrm{i}=1}^{\mathrm{n}} \mathrm{u}_{\mathrm{i}}\left(\mathrm{q}_{\mathrm{i}}\right)$, subject to the budget constraint, $\mathrm{M}=\sum_{\mathrm{i}=1}^{\mathrm{n}} \mathrm{p}_{\mathrm{i}} \mathrm{q}_{\mathrm{i}}$. Differentiating the budget constraint with respect to income and $\mathrm{p}_{\mathrm{j}}$ yields $\sum_{\mathrm{i}=1}^{\mathrm{n}} \partial\left(\mathrm{p}_{\mathrm{i}} \mathrm{q}_{\mathrm{i}}\right) / \partial \mathrm{M}=1$ and $\sum_{\mathrm{i}=1}^{\mathrm{n}} \mathrm{p}_{\mathrm{i}}\left(\partial \mathrm{q}_{\mathrm{i}} / \partial \mathrm{p}_{\mathrm{j}}\right)+\mathrm{q}_{\mathrm{j}}=0$, which can be expressed as

$$
\sum_{i=1}^{n} w_{i} \eta_{i}=1, \quad \sum_{i=1}^{n} w_{i} \eta_{i j}+w_{j}=0
$$

Denoting by $\lambda$ the marginal utility of income, the $\mathrm{i}^{\text {th }}$ first-order condition for a budgetconstrained utility maximum is $\log u_{i}^{\prime}=\log \lambda+\log p_{i}$, where the prime denotes a first derivative. Using $\sum_{\mathrm{i}=1}^{\mathrm{n}} \mathrm{u}_{\mathrm{i}}\left(\mathrm{q}_{\mathrm{i}}\right)$, we differentiate the first-order condition with respect to $\log \mathrm{M}$ and $\log \mathrm{p}_{\mathrm{j}}$ to yield

$$
\frac{\partial \log u_{i}^{\prime}}{\partial \log q_{i}} \eta_{i}=\phi^{-1}, \quad \frac{\partial \log u_{i}^{\prime}}{\partial \log q_{i}} \eta_{i j}=\frac{\partial \log \lambda}{\partial \log p_{j}}+\delta_{i j},
$$

where $\phi^{-1}=\partial(\log \lambda) / \partial(\log M)$ is the income elasticity of $\lambda$ (the reciprocal of the "income flexibility") and $\delta_{\mathrm{ij}}$ is the Kronecker delta $\left(\delta_{\mathrm{ij}}=1\right.$ if $\mathrm{i}=\mathrm{j}, 0$ otherwise $){ }^{3}$ Combining the above two equations gives

$$
\eta_{\mathrm{ij}}=\phi \frac{\partial \log \lambda}{\partial \log p_{\mathrm{j}}} \eta_{\mathrm{i}}+\delta_{\mathrm{ij}} \phi \eta_{\mathrm{i}}
$$

which we multiply by the budget share of $i, w_{i}$, and then sum both sides over $i=1, \ldots, n$ to give

$$
\sum_{i=1}^{\mathrm{n}} \mathrm{w}_{\mathrm{i}} \eta_{\mathrm{ij}}=\phi \frac{\partial \log \lambda}{\partial \log \mathrm{p}_{\mathrm{j}}} \sum_{\mathrm{i}=1}^{\mathrm{n}} \mathrm{w}_{\mathrm{i}} \eta_{\mathrm{i}}+\phi \sum_{\mathrm{i}=1}^{\mathrm{n}} \delta_{\mathrm{ij}} \mathrm{w}_{\mathrm{i}} \eta_{\mathrm{i}}=\phi \frac{\partial \log \lambda}{\partial \log \mathrm{p}_{\mathrm{j}}}+\phi \mathrm{w}_{\mathrm{j}} \eta_{\mathrm{j}}
$$

\footnotetext{
${ }^{3}$ In the general case in which there is preference dependence, the marginal utility of good $\mathrm{i}, \partial \mathrm{u} / \partial \mathrm{q}_{\mathrm{i}}$, depends on the consumption of all goods and

$$
\frac{\partial\left(\log \partial u / \partial q_{i}\right)}{\partial(\log x)}=\sum_{j=1}^{n} \frac{\partial\left(\log \partial u / \partial q_{i}\right)}{\partial\left(\log q_{j}\right)} \frac{\partial\left(\log q_{j}\right)}{\partial(\log x)}, x=M, p_{j}, j=1, \ldots, n .
$$

Under preference independence, the cross derivatives vanish and only the ith term in the summation on the right of this equation remains.
} 
which follows from the first member of (2). Combining this with the second member of (2) gives $\partial \log \lambda / \partial \log \mathrm{p}_{\mathrm{j}}=-\mathrm{w}_{\mathrm{j}}\left(\eta_{\mathrm{j}}+\phi^{-1}\right)$, which when substituted back into (3), yields

$$
\eta_{\mathrm{ij}}=\phi \eta_{\mathrm{i}}\left(\delta_{\mathrm{ij}}-\mathrm{w}_{\mathrm{j}} \eta_{\mathrm{j}}\right)-\mathrm{w}_{\mathrm{j}} \eta_{\mathrm{i}} \cdot
$$

\section{Application to Food}

We use equations (1) and (4) to derive the compensated price elasticities. The uncompensated elasticities for seven food items are from Cornelsen et al. (2014) and the budget shares $\mathrm{w}_{\mathrm{j}}$ are from the 2005 International Comparison Program (World Bank, unpublished). We treat the values of the seven income elasticities $\eta_{1}, \ldots, \eta_{7}$ and the income flexibility as unknown. The income elasticities of the food items are a weighted average of the income elasticity of all food $\left(\eta_{\mathrm{F}}\right)$, available from Gao (2012):

$$
\sum_{i=1}^{7}\left(\frac{w_{i}}{W_{F}}\right) \eta_{i}=\eta_{F}
$$

where $\mathrm{W}_{\mathrm{F}}=\sum_{\mathrm{i}=1}^{7} \mathrm{~W}_{\mathrm{i}}$ is the budget share of all food. Equation (4) for $\mathrm{i}, \mathrm{j}=1, \ldots 7$ is a system of 49 equations which is overdetermined and has no exact unique solution. Thus, we add an error term $\left(\varepsilon_{\mathrm{ij}}\right)$ to give $\eta_{\mathrm{ij}}=\phi \eta_{\mathrm{i}}\left(\delta_{\mathrm{ij}}-\mathrm{w}_{\mathrm{j}} \eta_{\mathrm{j}}\right)-\mathrm{w}_{\mathrm{j}} \eta_{\mathrm{i}}+\varepsilon_{\mathrm{ij}}$ and then minimise the sum of squared errors:

$$
\operatorname{Min}_{\eta_{1}, \ldots, \eta_{7}, \phi} \sum_{i=1}^{7} \sum_{j=1}^{7}\left[\eta_{i j}-\phi \eta_{i}\left(\delta_{i j}-w_{j} \eta_{j}\right)+w_{j} \eta_{i}\right]^{2},
$$

subject to constraint (5) for a given value of $\eta_{\mathrm{F}}$ and the constraint that all income elasticities are positive.

Table 1 gives the budget shares for the food items and the total, as well as the food income elasticity. Two comments can be made. First, column 9 reveals that low-income countries on average spend 35 percent of their income on food, while this falls to 9 percent for the high-income countries, which reflects Engel's law. Second, cereals are clearly the single most important item in low-income countries (column 6) with a budget share of 11 percent. For the high-income countries, there is more diversification of food spending, with no single commodity clearly dominating.

\footnotetext{
${ }^{4}$ Under preference independence, income elasticities are positive.
} 
The solution to problem (6) yields estimates of seven income elasticities and the income flexibility, to be denoted by $\hat{\eta}_{1}, \ldots, \hat{\eta}_{7}$ and $\hat{\phi}$. There are then two ways of deriving the compensated elasticities:

- Approach I: Combine equations (1) and (4) and then substitute the estimated income elasticities and the income flexibility, together with the budget shares. This gives the estimated compensated elasticities, $\hat{\eta}_{\mathrm{ij}}^{*}=\hat{\phi} \hat{\eta}_{\mathrm{i}}\left(\delta_{\mathrm{ij}}-\mathrm{w}_{\mathrm{j}} \hat{\eta}_{\mathrm{j}}\right), \mathrm{i}, \mathrm{j}=1, \ldots, 7$.

- Approach II: Substitute into Slutsky equation (1) the uncompensated elasticities from Cornelsen et al. (2014), the budget shares and the estimates of the income elasticities. This gives an alternative set of estimated compensated elasticities, $\tilde{\eta}_{i j}^{*}=\eta_{i j}+w_{j} \hat{\eta}_{i}$, $\mathrm{i}, \mathrm{j}=1, \ldots, 7$.

The difference between the two approaches is that the second does not rely so much on the assumption of preference independence as equation (4) is bypassed. Thus, this approach might possibly be preferred as it is somewhat more general. However, as minimisation problem (6) is based on preference independence, that assumption still plays a role in determining the estimated income elasticities. A further difference is that the estimates from Approach I satisfy demand homogeneity and Slutsky symmetry, while this is not the case for Approach II. ${ }^{5}$ In what follows, we present the results from Approach I, although these are not too different from those of Approach II (see Appendix).

\section{Results}

The estimated income elasticities and income flexibility are given in Table 2 and as can be seen, all the food income elasticities are less than unity, so the goods are necessities. For each of the three income groups, the item "Fish" has the highest income elasticity, whilst "Cereals" and "Fats and oils" have the lowest and are thus viewed as more of necessities by consumers. The absolute value of the income flexibility increases with income, which supports the famous conjecture by Frisch (1959, p. 189), but the values are somewhat larger in absolute value than previous estimates (Clements and Zhao, 2009, pp. 227-29).

The estimated compensated price elasticities are given in Table 3. Thus, for example, for low income countries the compensated own-price elasticity for Fruit and Vegetables is -0.669 (first element of column 2), while the corresponding uncompensated version is -0.720

\footnotetext{
${ }^{5}$ A set of sufficient conditions for the two approaches to give identical results this is when the income flexibility equals -1 , each income elasticity is unity, each uncompensated own-price elasticity -1 and each uncompensated cross-price elasticity zero. These conditions are satisfied by a Cobb-Douglas utility function, but are restrictive.
} 
(Cornelsen et al., 2014). Table 4 reports the compensated/uncompensated differences, which are the income effects. Three comments can be made. First, as indicated by equation (1), the size of the income effect depends on the relative importance of the good in the budget (its budget share) and the income elasticity. As both these concepts take only modest values in the case of the seven food items, the income effects will also be modest, as Table 4 reveals. Second, the largest income effect is for meat in low-income countries, which reflects the combined effect of this good's relatively high budget share and income elasticity. Third, all income effects decline as we move from low- to medium- to high-income countries. The reason is that as income rises, the budget share and the income elasticity of each food item declines. ${ }^{6}$ The decline in the compensated elasticities is consistent with Timmer's (1980) hypothesis of a "curvature" in the Slutsky matrix.

\section{Concluding Comments}

When the objective is to use a tax instrument to limit consumption of a certain item by raising its price to consumers, the value of the price elasticity of demand is key. The rule is

$$
\text { Required price increase }=\frac{\text { Requred reduction in consumption }}{\text { Price elasticity }} .
$$

For example, a 25-percent reduction in consumption requires a 50-percent price increase if the elasticity is $-1 / 2$. There are two types of price elasticity, (i) the uncompensated version that holds constant consumers' money (or nominal) income; and (ii) the compensated version in which real income is constant. Both the uncompensated and compensated elasticities contain information that is of considerable value to policy makers in understanding consumer response to price changes that result from policy changes.

Cornelsen et al. (2014) and Green et al. (2013) made a major contribution in reviewing a large number of recent studies of food demand and summarising the price elasticities for seven important food items with a meta-regression approach. In this letter, we showed how to covert these uncompensated elasticities into their compensated counterparts. The difference between the two elasticities depends on the relative importance of the good in consumers' budgets and the income elasticity. In the case of the seven food items, these differences are not large, but still the compensated elasticities could be of some use. To reflect the underlying uncertainty of behaviour, the two elasticities could be used together to

\footnotetext{
${ }^{6}$ Using the estimates of the compensated elasticities from Approach I, together with the budget shares and the estimated income elasticities, in equation (1) gives estimates of the uncompensated elasticities, $\hat{\eta}_{\mathrm{ij}}$. As shown in the Appendix, the estimated own-price uncompensated elasticities are very close to their actual counterparts. However, the estimated cross-price elasticities are a good distance away from the actuals.
} 
provide a range of possible consumer responses when modelling the impact of food taxes/subsidies. 


\section{References}

Clements, K. W. and X. Zhao (2009). Economics and Marijuana: Consumption, Pricing and Legalisation. Cambridge: Cambridge University Press.

Cornelsen, L., R. Green, R. Turner, A. D. Dangour, B. Shankar, M. Mazzocchi and R. D. Smith (2014). "What Happens to Patterns of Food Consumption When Food Prices Change? Evidence from a Systematic Review and Meta-analysis of Food Price Elasticities Globally." Health Economics [Online version before inclusion in an issue].

Gao, G. (2012). “World Food Demand.” American Journal of Agricultural Economics 94: 2551.

Frisch, R. (1959). "A Complete Scheme for Computing All Direct and Cross Demand Elasticities in a Model with Many Sectors." Econometrica 27: 177-96.

Green, R., L. Cornelsen, A. D. Dangour, B. Shankar, M. Mazzocchi and R. D. Smith (2013). "The Effect of Rising Food Prices on Food Consumption: Systematic Review with Meta-Regression.” British Medical Journal 346: f3703.

Timmer, C. P. (1980). "Is there 'Curvature' in the Slutsky Matrix?" Review of Economics and Statistics 63: 395-402.

World Bank (unpublished). "Confidential Basic Headings Expenditure Spreadsheet." 2005 International Comparison Program. World Bank.

Table 1 Food budget shares and income elasticities

\begin{tabular}{|c|c|c|c|c|c|c|c|c|c|}
\hline \multirow{2}{*}{$\begin{array}{l}\text { Income } \\
\text { group }\end{array}$} & \multicolumn{8}{|c|}{ Budget shares $\mathrm{w}_{\mathrm{i}}, \mathrm{W}_{\mathrm{F}}$} & \multirow{3}{*}{$\begin{array}{c}\text { Food income } \\
\text { elasticity } \\
\eta_{\mathrm{F}} \\
(10)\end{array}$} \\
\hline & $\begin{array}{l}\text { Fruits } \\
\& \text { vegs }\end{array}$ & Meat & Fish & Dairy & Cereals & $\begin{array}{c}\text { Fats and } \\
\text { oils }\end{array}$ & Sweets & $\begin{array}{l}\text { Total } \\
\text { food }\end{array}$ & \\
\hline (1) & (2) & (3) & (4) & (5) & (6) & (7) & (8) & (9) & \\
\hline Low & 0.089 & 0.068 & 0.030 & 0.030 & 0.112 & 0.024 & 0.021 & 0.353 & 0.819 \\
\hline Medium & 0.042 & 0.051 & 0.010 & 0.025 & 0.036 & 0.009 & 0.013 & 0.186 & 0.517 \\
\hline High & 0.020 & 0.023 & 0.008 & 0.012 & 0.016 & 0.003 & 0.008 & 0.089 & 0.313 \\
\hline
\end{tabular}

Notes:

1. Budget shares are calculated using the disaggregated expenditure data from the International Comparison Program (ICP) dataset supplied by the World Bank (unpublished). See the Appendix for details.

2. Food income elasticities from Gao (2012) are averaged across countries by income group.

Table 2 Estimated income elasticities and income flexibility

\begin{tabular}{ccccccccccc}
\hline \hline \multirow{2}{*}{$\begin{array}{c}\text { Income } \\
\text { group }\end{array}$} & $\begin{array}{c}\text { Fruits \& } \\
\text { vegs }\end{array}$ & Meat & Fish & Dairy & Cereals & $\begin{array}{c}\text { Fats and } \\
\text { oils }\end{array}$ & Sweets & $\begin{array}{c}\text { Non- } \\
\text { food }\end{array}$ & $\begin{array}{c}\text { Income } \\
\text { flexibility } \phi\end{array}$ \\
$(1)$ & $(2)$ & $(3)$ & $(4)$ & $(5)$ & $(6)$ & $(7)$ & $(8)$ & $(9)$ & $(10)$ \\
\hline Low & 0.827 & 0.888 & 0.902 & 0.886 & 0.756 & 0.681 & 0.851 & 1.108 & -0.873 \\
Medium & 0.508 & 0.560 & 0.573 & 0.564 & 0.432 & 0.426 & 0.537 & 1.110 & -1.265 \\
High & 0.304 & 0.344 & 0.351 & 0.345 & 0.248 & 0.242 & 0.322 & 1.067 & -1.736 \\
\hline
\end{tabular}


Table 3 Compensated price elasticities

\begin{tabular}{|c|c|c|c|c|c|c|c|c|}
\hline $\begin{array}{c}\text { Group } \\
(1)\end{array}$ & $\begin{array}{c}\text { Fruits \& } \\
\text { vegetables } \\
(2)\end{array}$ & $\begin{array}{c}\text { Meat } \\
(3)\end{array}$ & $\begin{array}{l}\text { Fish } \\
(4)\end{array}$ & $\begin{array}{c}\text { Dairy } \\
(5) \\
\end{array}$ & $\begin{array}{c}\text { Cereals } \\
(6)\end{array}$ & $\begin{array}{c}\text { Fats and } \\
\text { oils } \\
(7)\end{array}$ & $\begin{array}{c}\text { Sweets } \\
\text { (8) }\end{array}$ & $\begin{array}{l}\text { Non- } \\
\text { Food } \\
(9)\end{array}$ \\
\hline & \multicolumn{8}{|c|}{ A. Low Income } \\
\hline Fruits \& vegetables & -0.669 & 0.043 & 0.019 & 0.019 & 0.061 & 0.012 & 0.013 & 0.500 \\
\hline Meat & 0.057 & -0.728 & 0.021 & 0.021 & 0.066 & 0.013 & 0.014 & 0.537 \\
\hline Fish & 0.058 & 0.047 & -0.766 & 0.021 & 0.067 & 0.013 & 0.014 & 0.546 \\
\hline Dairy & 0.057 & 0.047 & 0.021 & -0.753 & 0.065 & 0.013 & 0.014 & 0.536 \\
\hline Cereals & 0.048 & 0.040 & 0.018 & 0.018 & -0.604 & 0.011 & 0.012 & 0.458 \\
\hline Fats and oils & 0.044 & 0.036 & 0.016 & 0.016 & 0.050 & -0.585 & 0.011 & 0.413 \\
\hline Sweets & 0.055 & 0.045 & 0.020 & 0.020 & 0.063 & 0.012 & -0.729 & 0.515 \\
\hline \multirow[t]{2}{*}{ Non-Food } & 0.071 & 0.058 & 0.026 & 0.026 & 0.082 & 0.016 & 0.018 & -0.296 \\
\hline & \multicolumn{8}{|c|}{ B. Medium Income } \\
\hline Fruits \& vegetables & -0.629 & 0.018 & 0.004 & $0 . \overline{009}$ & $\overline{0.010}$ & 0.002 & 0.004 & 0.581 \\
\hline Meat & 0.015 & -0.688 & 0.004 & 0.010 & 0.011 & 0.003 & 0.005 & 0.641 \\
\hline Fish & 0.015 & 0.021 & -0.721 & 0.010 & 0.011 & 0.003 & 0.005 & 0.656 \\
\hline Dairy & 0.015 & 0.020 & 0.004 & -0.703 & 0.011 & 0.003 & 0.005 & 0.645 \\
\hline Cereals & 0.012 & 0.016 & 0.003 & 0.008 & -0.538 & 0.002 & 0.004 & 0.495 \\
\hline Fats and oils & 0.011 & 0.015 & 0.003 & 0.007 & 0.008 & -0.537 & 0.004 & 0.487 \\
\hline Sweets & 0.014 & 0.019 & 0.004 & 0.009 & 0.011 & 0.003 & -0.674 & 0.614 \\
\hline \multirow[t]{2}{*}{ Non-Food } & 0.030 & 0.040 & 0.008 & 0.019 & 0.022 & 0.005 & 0.010 & -0.135 \\
\hline & \multicolumn{8}{|c|}{ C. High Income } \\
\hline Fruits \& vegetables & -0.524 & 0.004 & 0.001 & $0.0 \overline{02}$ & $\overline{0.002}$ & 0.000 & 0.001 & 0.512 \\
\hline Meat & 0.004 & -0.593 & 0.002 & 0.002 & 0.002 & 0.000 & 0.002 & 0.581 \\
\hline Fish & 0.004 & 0.005 & -0.607 & 0.002 & 0.002 & 0.000 & 0.002 & 0.592 \\
\hline Dairy & 0.004 & 0.005 & 0.002 & -0.596 & 0.002 & 0.000 & 0.002 & 0.581 \\
\hline Cereals & 0.003 & 0.003 & 0.001 & 0.002 & -0.428 & 0.000 & 0.001 & 0.418 \\
\hline Fats and oils & 0.002 & 0.003 & 0.001 & 0.002 & 0.002 & -0.419 & 0.001 & 0.408 \\
\hline Sweets & 0.003 & 0.004 & 0.002 & 0.002 & 0.002 & 0.000 & -0.558 & 0.544 \\
\hline Non-Food & 0.011 & 0.014 & 0.005 & 0.008 & 0.007 & 0.001 & 0.005 & -0.052 \\
\hline
\end{tabular}

Note:

To complete the demand system, a "non-food" group is added so there are $n=7+1=8$ goods. The non-food income elasticity is derived from the requirement that $\sum_{\mathrm{i}=1}^{8} \mathrm{w}_{\mathrm{i}} \eta_{\mathrm{i}}=1$, where $\mathrm{w}_{\mathrm{i}}$ and $\eta_{\mathrm{i}}$ are the budget share and income elasticity of good $\mathrm{i}$, with $\mathrm{w}_{8}=1-\sum_{\mathrm{i}=1}^{7} \mathrm{w}_{\mathrm{i}}$ the non-food budget share.

Table 4 Income effects of price changes

\begin{tabular}{|c|c|c|c|c|c|c|c|}
\hline $\begin{array}{c}\text { Group } \\
(1)\end{array}$ & $\begin{array}{c}\text { Fruits \& } \\
\text { vegetables } \\
\text { (2) }\end{array}$ & $\begin{array}{c}\text { Meat } \\
\text { (3) }\end{array}$ & $\begin{array}{c}\text { Fish } \\
\text { (4) }\end{array}$ & $\begin{array}{c}\text { Dairy } \\
(5)\end{array}$ & $\begin{array}{c}\text { Cereals } \\
(6)\end{array}$ & $\begin{array}{c}\text { Fats and } \\
\text { oils } \\
(7)\end{array}$ & $\begin{array}{c}\text { Sweets } \\
(8)\end{array}$ \\
\hline \multicolumn{8}{|c|}{ A. Low Income } \\
\hline Uncompensated elasticity $\eta_{\mathrm{ii}}$ & -0.720 & -0.780 & -0.800 & -0.780 & -0.610 & -0.600 & -0.740 \\
\hline Compensated elasticity $\hat{\eta}_{\mathrm{ii}}^{*}$ & -0.669 & -0.728 & -0.766 & -0.753 & -0.604 & -0.585 & -0.729 \\
\hline Income effect & 0.051 & 0.052 & 0.034 & 0.027 & 0.006 & 0.015 & 0.011 \\
\hline \multicolumn{8}{|c|}{ B. Medium Income } \\
\hline Uncompensated elasticity $\eta_{\mathrm{ii}}$ & -0.650 & -0.720 & -0.730 & -0.720 & -0.550 & -0.540 & -0.680 \\
\hline Compensated elasticity $\hat{\eta}_{\mathrm{ii}}^{*}$ & -0.629 & -0.688 & -0.721 & -0.703 & -0.538 & -0.537 & -0.674 \\
\hline Income effect & 0.021 & 0.032 & 0.009 & 0.017 & 0.012 & 0.003 & 0.006 \\
\hline \multicolumn{8}{|c|}{ C. High Income } \\
\hline Uncompensated elasticity $\eta_{\mathrm{ii}}$ & -0.530 & -0.600 & -0.610 & -0.600 & -0.430 & -0.420 & -0.560 \\
\hline Compensated elasticity $\hat{\eta}_{\mathrm{ii}}^{*}$ & -0.524 & -0.593 & -0.607 & -0.596 & -0.428 & -0.419 & -0.558 \\
\hline Income effect & 0.006 & 0.007 & 0.003 & 0.004 & 0.002 & 0.001 & 0.002 \\
\hline
\end{tabular}

Uncompensated elasticities are from Cornelsen et al. (2014) and compensated elasticities from Table 3. 


\section{Appendix}

\section{The Data}

Uncompensated price elasticities from Cornelsen et al. (2014) are reproduced in Table A1. Purchasing power parities and nominal expenditures on 129 disaggregated components of GDP in 146 countries are from the 2005 International Comparison Program (ICP) data (World Bank, unpublished). The 29 food categories and their broad group classifications are given in Table A2. The commodities in the last four rows of Table A2 would typically be considered as part of food consumption; however, Cornelsen et al. (2014) omit price elasticities for "Eggs" and "Other foods" due to the low number of observations for the former and the majority of observations coming from one study for the latter. Therefore, we omit these groups.

Of the 146 countries in the ICP data, 16 countries were dropped as they had little or no expenditure on certain food items, be it for income, geographical, religious or other reasons. Two more countries were also dropped as they did not submit national accounts data to the ICP. Lastly, four remaining countries were omitted as they did not appear in the Gao (2012), the source of the income elasticity for food. The number of countries is thus $146-16-2-4=124$ countries.

\section{Income Groups}

Countries are grouped by income using the approach of Cornelsen et al. (2014), which is based on Muhammad et al. (2011). They divide countries into low-, middle-, and highincome countries on the basis of their real income per capita relative to that of the United States, using the 2005 ICP data. Low-income countries are those with 15 percent or less income relative to the United States, middle-income are those between 15 and 45 percent, while high-income countries have income equal to or greater than 45 percent the United States. We cross-checked our 124 countries with those reported Muhammad et al. (2011) to ensure income groups are properly assigned and they agree with the dataset that Cornelsen et al. (2014) sent us. The 124 countries, and the income groupings, are listed in Table A3 along with our own calculations of real income per capita. While this allocation of countries to income groups agrees with Cornelsen et al. (2014) and Muhammad et al. (2011), there are some minor inconsistencies with income. Our measure of real income per capita that is presented in Table A3 differs slightly from Muhammad et al. (2011). It is for this reason why some low-income countries have higher incomes than middle income countries. Take the 
case of country 58, Tajikistan, which has an income of $\$ 7,010$ and is classified as a lowincome country. But this income is higher than that of countries 59-66, all of which are classified as middle-income countries. A similar problem occurs with countries near the highincome "border". We judge this issue to be of relatively minor importance that is unlikely to have a substantial impact on the results.

\section{More on Preference Independence}

Combining equations (1) and (4), under preference independence the compensated elasticities are related to the income elasticities according to

$$
\eta_{i j}^{*}=\phi \eta_{i}\left(\delta_{i j}-w_{j} \eta_{j}\right), i, j=1, \ldots, n .
$$

Preference independence also implies that the income elasticities are positive, which, as $\phi<0$, means that $\eta_{\mathrm{ij}}^{*}>0, \mathrm{i} \neq \mathrm{j}$.

\section{Approach II for Compensated Elasticities}

Compensated elasticities estimated from Approach II are given in Table A4. Note the similarities in estimated values compared to Approach I in Table 3 of the text. When Approach II is used, there is a tendency for the absolute values of the elasticities to be lower compared to Approach I, but most of the differences are small. Figure A1 confirms the closeness of the two sets of results for the own-price elasticities. The only item some distance away from the 45-degree line is cereals, especially for the low-income countries, reflecting the large budget share of this good. As the compensated elasticity estimates are similar for both approaches, they also yield broadly similar income effects.

Note that the two approaches give identical results when $\hat{\phi} \hat{\eta}_{i}\left(\delta_{i j}-w_{j} \hat{\eta}_{j}\right)=\eta_{i j}+w_{j} \hat{\eta}_{i}$. A set of sufficient conditions for this is when the income flexibility equals -1 , each income elasticity is unity, each uncompensated own-price elasticity -1 and each uncompensated cross-price elasticity zero. These are restrictive conditions.

\section{The Implied Uncompensated Elasticities}

Table A5 contains the estimated uncompensated elasticities using Approach I. These are obtained from equation (1) by substituting into the right-hand side the estimated compensated elasticities of Table 3 and the budget shares and income elasticities of Tables 1 and 2, respectively. Figure A2 demonstrates that for the own-price uncompensated elasticities, the estimates from Approach I and actual values are in close agreement, with the 
possible exception of cereals. As for Approach II actual and estimated coincide, a similar comparison is not meaningful.

\section{$\underline{\text { Cross Price Elasticities }}$}

For the estimated uncompensated cross-price elasticities (unreported), they are a good distance away from the actuals from in Cornelsen et al. (2014). This reflects the nature of problem (6): The own-price elasticities from Cornelsen et al. (2014) are large relative to the own-price elasticities, so the squared errors of the former also tend to be relatively large. As all the squared errors (the own- and cross-price ones) are summed, the solution to the minimisation problem emphasises accurate prediction the own-price elasticities at the expense of the cross-price elasticities. Such an implication is not unreasonable as the ownprice elasticities are more economically important than the cross-price ones.

\section{$\underline{\text { References }}$}

Cornelsen, L., R. Green, R. Turner, A. D. Dangour, B. Shankar, M. Mazzocchi and R. D. Smith (2014). "What Happens to Patterns of Food Consumption When Food Prices Change? Evidence from a Systematic Review and Meta-analysis of Food Price Elasticities Globally." Health Economics [Online version before inclusion in an issue].

Gao, G. (2012). "World Food Demand.” American Journal of Agricultural Economics 94: 2551.

Muhammad, A., J. L. Seale, Jr., B. Meade and A. Regmi (2011). "International Evidence on Food Consumption Patterns: An Update Using 2005 International Comparison Program Data." Technical Bulletin Number 1929, United States Department of Agriculture, Economic Research Service. Revised February 2013. 
Table A1 Uncompensated price elasticities from Cornelsen et al. (2014)

\begin{tabular}{|c|c|c|c|c|c|c|c|c|}
\hline Commodity & $\begin{array}{c}\text { Fruits \& } \\
\text { vegetables }\end{array}$ & Meat & Fish & Dairy & Cereals & $\begin{array}{c}\text { Fats and } \\
\text { oils }\end{array}$ & Sweets & $\begin{array}{l}\text { Non- } \\
\text { Food }\end{array}$ \\
\hline & \multicolumn{8}{|c|}{ A. Low Income } \\
\hline Fruits \& vegetables & -0.720 & 0.005 & -0.014 & -0.001 & 0.065 & -0.014 & 0.112 & - \\
\hline Meat & 0.020 & -0.780 & -0.008 & 0.011 & 0.062 & 0.016 & 0.101 & - \\
\hline Fish & 0.014 & 0.045 & -0.800 & -0.003 & 0.092 & 0.031 & 0.098 & - \\
\hline Dairy & -0.001 & 0.003 & -0.020 & -0.780 & 0.117 & 0.042 & 0.108 & - \\
\hline Cereals & 0.009 & 0.003 & -0.010 & 0.068 & -0.610 & 0.006 & 0.100 & - \\
\hline Fats and oils & 0.012 & -0.043 & -0.061 & 0.022 & 0.071 & -0.600 & 0.094 & - \\
\hline Sweets & 0.022 & 0.003 & -0.004 & 0.033 & 0.074 & 0.022 & -0.740 & - \\
\hline \multirow[t]{2}{*}{ Non-Food } & - & - & - & - & - & - & - & - \\
\hline & \multicolumn{8}{|c|}{ B. Medium Income } \\
\hline Fruits \& vegetables & -0.650 & -0.026 & -0.079 & -0.058 & 0.007 & -0.039 & 0.034 & - \\
\hline Meat & 0.001 & -0.720 & -0.073 & -0.045 & 0.005 & -0.010 & 0.024 & - \\
\hline Fish & -0.004 & 0.014 & -0.730 & -0.059 & 0.035 & 0.005 & 0.021 & - \\
\hline Dairy & -0.020 & -0.028 & -0.085 & -0.720 & 0.060 & 0.016 & 0.031 & - \\
\hline Cereals & -0.010 & -0.028 & -0.076 & 0.012 & -0.550 & -0.020 & 0.023 & - \\
\hline Fats and oils & -0.006 & -0.074 & -0.126 & -0.035 & 0.014 & -0.540 & 0.017 & - \\
\hline Sweets & 0.003 & -0.028 & -0.069 & -0.024 & 0.017 & -0.003 & -0.680 & - \\
\hline \multirow[t]{2}{*}{ Non-Food } & - & - & - & - & - & - & - & - \\
\hline & \multicolumn{8}{|c|}{ C. High Income } \\
\hline Fruits \& vegetables & -0.530 & 0.002 & 0.010 & -0.030 & 0.048 & -0.033 & 0.060 & - \\
\hline Meat & -0.009 & -0.600 & 0.016 & -0.018 & 0.045 & -0.003 & 0.049 & - \\
\hline Fish & -0.015 & 0.042 & -0.610 & -0.032 & 0.075 & 0.012 & 0.046 & - \\
\hline Dairy & -0.030 & 0.001 & 0.004 & -0.600 & 0.100 & 0.023 & 0.057 & - \\
\hline Cereals & -0.020 & 0.000 & 0.013 & 0.039 & -0.430 & -0.013 & 0.048 & - \\
\hline Fats and oils & -0.017 & -0.046 & -0.037 & -0.007 & 0.054 & -0.420 & 0.043 & - \\
\hline Sweets & -0.007 & 0.000 & 0.020 & 0.004 & 0.057 & 0.003 & -0.560 & - \\
\hline Non-Food & - & - & - & - & - & - & - & - \\
\hline
\end{tabular}


Table A2 ICP Basic Headings

\begin{tabular}{|c|c|c|}
\hline $\begin{array}{l}\text { No. } \\
(1)\end{array}$ & $\begin{array}{l}\text { ICP Category } \\
\text { (2) }\end{array}$ & $\begin{array}{l}\text { Assigned Group } \\
\text { (3) }\end{array}$ \\
\hline 1. & 1101111 Rice & Cereals \\
\hline 2. & 1101112 Other cereals and flour & Cereals \\
\hline 3. & 1101113 Bread & Cereals \\
\hline 4. & 1101114 Other bakery products & Cereals \\
\hline 5. & 1101115 Pasta products & Cereals \\
\hline 6. & 1101121 Beef and veal & Meat \\
\hline 7. & 1101122 Pork & Meat \\
\hline 8. & 1101123 Lamb, mutton and goat & Meat \\
\hline 9. & 1101124 Poultry & Meat \\
\hline 10. & 1101125 Other meats and preparations & Meat \\
\hline 11. & 1101131 Fresh or frozen fish and seafood & Fish \\
\hline 12. & 1101132 Preserved fish and seafood & Fish \\
\hline 13. & 1101141 Fresh milk & Dairy \\
\hline 14. & 1101142 Preserved milk and milk products & Dairy \\
\hline 15. & 1101143 Cheese & Dairy \\
\hline 16. & 1101151 Butter and margarine & Fats and oils \\
\hline 17. & 1101153 Other edible oils and fats & Fats and oils \\
\hline 18. & 1101161 Fresh or chilled fruit & Fruits and vegetables \\
\hline 19. & 1101162 Frozen, preserved or processed fruits & Fruits and vegetables \\
\hline 20. & 1101171 Fresh or chilled vegetables & Fruits and vegetables \\
\hline 21. & 1101172 Fresh or chilled potatoes & Fruits and vegetables \\
\hline 22. & 1101173 Frozen or preserved vegetables & Fruits and vegetables \\
\hline 23. & 1101181 Sugar & Sweets \\
\hline 24. & 1101182 Jams, marmalades and honey & Sweets \\
\hline 25. & 1101183 Confectionery, chocolate and ice cream & Sweets \\
\hline 26. & 1101144 Eggs and egg-based products & Omitted \\
\hline 27. & 110119 Food products n.e.c. & Omitted \\
\hline 28. & 110121 Coffee, tea and cocoa & Omitted \\
\hline 29. & 110122 Mineral waters, soft drinks, fruit and vegetable juices & Omitted \\
\hline
\end{tabular}

Source: World Bank (unpublished). 
Table A3 Countries by income group

\begin{tabular}{|c|c|c|c|c|c|}
\hline$\#$ & $\begin{array}{l}\text { Country } \\
\text { (2) }\end{array}$ & $\begin{array}{c}\text { Real income per capita. } \\
\text { (\$US, PPP) } \\
(3)\end{array}$ & $\begin{array}{l}\# \\
(4) \\
\end{array}$ & $\begin{array}{l}\text { Country } \\
(5)\end{array}$ & $\begin{array}{c}\text { Real income per capita } \\
\text { (\$US, PPP) } \\
(6)\end{array}$ \\
\hline & A. Low Income & & 63. & Uruguay & 6,477 \\
\hline 1. & Guinea-Bissau & 338 & 64. & South Africa & 6,720 \\
\hline 2. & Niger & 362 & 65. & Montenegro & 6,893 \\
\hline 3. & Liberia & 420 & 66. & Bosnia and Herzegovina & 6,921 \\
\hline 4. & Mozambique & 458 & 67. & Chile & 7,160 \\
\hline 5. & Central African Republic & 473 & 68. & Macedonia, FYR & 7,171 \\
\hline 6. & Rwanda & 669 & 69. & Argentina & 7,175 \\
\hline 7. & Malawi & 696 & 70. & Oman & 7,302 \\
\hline 8. & Burkina Faso & 704 & 71. & Saudi Arabia & 7,834 \\
\hline 9. & Nepal & 704 & 72. & Ukraine & 8,195 \\
\hline 10. & Côte d'Ivoire & 803 & 73. & Romania & 8,678 \\
\hline 11. & Madagascar & 844 & 74. & Serbia & 9,128 \\
\hline 12. & Sierra Leone & 905 & 75 . & Iran, Islamic Rep. & 9,137 \\
\hline 13. & Senegal & 928 & 76. & Bulgaria & 9,204 \\
\hline 14. & Guinea & 928 & 77. & Mauritius & 9,428 \\
\hline 15. & Benin & 955 & 78. & Mexico & 9,649 \\
\hline 16. & Ghana & 984 & 79. & Croatia & 10,223 \\
\hline 17. & Mauritania & 993 & 80 . & Russian Federation & 10,414 \\
\hline 18. & Cameroon & 1,158 & 81. & Kazakhstan & 10,996 \\
\hline 19. & Sudan & 1,242 & 82. & Macao, China & 11,235 \\
\hline 20. & São Tomé and Principe & 1,260 & 83. & Latvia & 11,711 \\
\hline 21. & Nigeria & 1,276 & 84. & Bahrain & 12,171 \\
\hline 22. & Kenya & 1,454 & 85. & Poland & 12,212 \\
\hline 23. & India & 1,488 & 86. & Slovak Republic & 12,230 \\
\hline 24. & Cambodia & 1,649 & 87. & Belarus & 12,309 \\
\hline 25 . & Yemen, Rep. & 1,710 & 88. & Lithuania & 12,709 \\
\hline 26. & Indonesia & 1,844 & 89. & Estonia & 12,764 \\
\hline 27. & Congo, Rep. & 1,870 & 90 . & Korea, Rep. & 13,533 \\
\hline 28. & China & 1,923 & 91. & Czech Republic & 13,944 \\
\hline 29. & Morocco & 1,964 & 92. & Hungary & 13,974 \\
\hline 30. & Pakistan & 1,975 & 93. & Slovenia & 14,956 \\
\hline 31. & Philippines & 2,071 & 94. & Brunei Darussalam & 15,380 \\
\hline 32. & Vietnam & 2,223 & 95. & Israel & 17,537 \\
\hline 33. & Iraq & 2,271 & \multicolumn{3}{|c|}{ C. High Income } \\
\hline 34. & Cape Verde & 2,456 & 96. & Portugal & 14,528 \\
\hline 35. & Mongolia & 2,663 & 97. & Kuwait & 15,838 \\
\hline 36. & Lesotho & 2,715 & 98. & Cyprus & 16,087 \\
\hline 37. & Sri Lanka & 2,781 & 99. & Singapore & 16,471 \\
\hline 38. & Paraguay & 2,948 & 100. & Malta & 16,911 \\
\hline 39. & Syrian Arab Republic & 3,330 & 101. & Greece & 17,510 \\
\hline 40. & Equatorial Guinea & 3,636 & 102. & New Zealand & 17,988 \\
\hline 41. & Swaziland & 3,709 & 103. & Qatar & 18,230 \\
\hline 42. & Fiji & 3,785 & 104. & Spain & 18,275 \\
\hline 43. & Namibia & 3,842 & 105. & Italy & 18,433 \\
\hline 44. & Peru & 4,161 & 106. & Finland & 20,322 \\
\hline 45. & Ecuador & 4,472 & 107. & Taiwan, China & 20,430 \\
\hline 46. & Bolivia & 4,562 & 108. & Hong Kong, China & 20,658 \\
\hline 47. & Tunisia & 4,616 & 109. & Germany & 20,799 \\
\hline 48. & Egypt, Arab Rep. & 4,691 & 110. & Ireland & 21,391 \\
\hline 49. & Jordan & 4,713 & 111. & Belgium & 21,563 \\
\hline 50. & Georgia & 4,715 & 112. & France & 21,966 \\
\hline 51. & Gabon & 4,870 & 113. & Japan & 22,088 \\
\hline 52. & Botswana & 4,955 & 114. & Denmark & 22,345 \\
\hline 53. & Kyrgyz Republic & 4,998 & 115. & Austria & 22,471 \\
\hline 54. & Azerbaijan & 5,251 & 116. & Australia & 22,519 \\
\hline 55. & Albania & 5,398 & 117. & Switzerland & 22,828 \\
\hline 56. & Armenia & 5,584 & 118. & Canada & 23,439 \\
\hline 57. & Moldova & 5,661 & 119. & Sweden & 23,866 \\
\hline 58. & Tajikistan & 7,010 & 120. & United Kingdom & 25,389 \\
\hline \multicolumn{3}{|c|}{ B. Middle Income } & 121. & Norway & 26,728 \\
\hline 59. & Venezuela, RB & 5,362 & 122. & Iceland & 28,308 \\
\hline 60. & Malaysia & 5,794 & 123. & United States & 29,999 \\
\hline 61. & Turkey & 6,139 & 124. & Luxembourg & 33,057 \\
\hline 62. & Brazil & 6,201 & & & \\
\hline
\end{tabular}

Note: Real income per capita in columns 3 and 6 is real total consumption, based on our own calculations using 2005 ICP data from the World Bank (unpublished). This is the sum over expenditures of the 116 consumption categories, each deflated by the population and the respective PPP. 
Table A4 Compensated price elasticities, Approach II

\begin{tabular}{|c|c|c|c|c|c|c|c|c|}
\hline $\begin{array}{c}\text { Group } \\
\text { (1) }\end{array}$ & $\begin{array}{c}\text { Fruits \& } \\
\text { vegetables } \\
\text { (2) }\end{array}$ & $\begin{array}{c}\text { Meat } \\
\text { (3) }\end{array}$ & $\begin{array}{l}\text { Fish } \\
\text { (4) }\end{array}$ & $\begin{array}{l}\text { Dairy } \\
(5)\end{array}$ & $\begin{array}{c}\text { Cereals } \\
\text { (6) }\end{array}$ & $\begin{array}{l}\text { Fats and } \\
\text { oils } \\
(7)\end{array}$ & $\begin{array}{c}\text { Sweets } \\
\text { (8) }\end{array}$ & $\begin{array}{c}\text { Non- } \\
\text { Food } \\
(9)\end{array}$ \\
\hline & \multicolumn{8}{|c|}{ A. Low Income } \\
\hline Fruits \& vegetables & -0.647 & 0.061 & 0.011 & 0.024 & 0.158 & 0.006 & 0.130 & - \\
\hline Meat & 0.099 & -0.720 & 0.018 & 0.038 & 0.161 & 0.038 & 0.120 & - \\
\hline Fish & 0.094 & 0.106 & -0.773 & 0.024 & 0.193 & 0.053 & 0.117 & - \\
\hline Dairy & 0.078 & 0.063 & 0.006 & -0.753 & 0.216 & 0.064 & 0.127 & - \\
\hline Cereals & 0.076 & 0.054 & 0.013 & 0.091 & -0.525 & 0.024 & 0.116 & - \\
\hline Fats and oils & 0.073 & 0.003 & -0.041 & 0.042 & 0.147 & -0.583 & 0.109 & - \\
\hline Sweets & 0.098 & 0.061 & 0.021 & 0.058 & 0.169 & 0.043 & -0.722 & - \\
\hline \multirow[t]{2}{*}{ Non-Food } & - & - & - & - & - & - & - & - \\
\hline & \multicolumn{8}{|c|}{ B. Medium Income } \\
\hline Fruits \& vegetables & -0.629 & 0.000 & -0.074 & -0.045 & 0.025 & -0.035 & 0.041 & - \\
\hline Meat & 0.024 & -0.691 & -0.067 & -0.031 & 0.025 & -0.005 & 0.031 & - \\
\hline Fish & 0.020 & 0.043 & -0.724 & -0.045 & 0.056 & 0.010 & 0.028 & - \\
\hline Dairy & 0.004 & 0.001 & -0.079 & -0.706 & 0.080 & 0.021 & 0.038 & - \\
\hline Cereals & 0.008 & -0.006 & -0.072 & 0.023 & -0.534 & -0.016 & 0.029 & - \\
\hline Fats and oils & 0.012 & -0.052 & -0.122 & -0.025 & 0.029 & -0.536 & 0.023 & - \\
\hline Sweets & 0.026 & -0.001 & -0.064 & -0.011 & 0.036 & 0.002 & -0.673 & - \\
\hline \multirow[t]{2}{*}{ Non-Food } & - & - & - & - & - & - & - & - \\
\hline & \multicolumn{8}{|c|}{ C. High Income } \\
\hline Fruits \& vegetables & -0.524 & 0.009 & 0.012 & -0.026 & 0.053 & -0.032 & 0.062 & - \\
\hline Meat & -0.002 & -0.592 & 0.019 & -0.014 & 0.051 & -0.002 & 0.052 & - \\
\hline Fish & -0.008 & 0.050 & -0.607 & -0.028 & 0.081 & 0.013 & 0.049 & - \\
\hline Dairy & -0.023 & 0.009 & 0.007 & -0.596 & 0.106 & 0.024 & 0.060 & - \\
\hline Cereals & -0.015 & 0.006 & 0.015 & 0.042 & -0.426 & -0.012 & 0.050 & - \\
\hline Fats and oils & -0.012 & -0.041 & -0.035 & -0.004 & 0.058 & -0.419 & 0.045 & - \\
\hline Sweets & -0.001 & 0.007 & 0.023 & 0.008 & 0.062 & 0.004 & -0.557 & - \\
\hline Non-Food & - & - & - & - & - & - & - & - \\
\hline
\end{tabular}

Note:

Denote by $\eta_{i j}$ the $(i, j)^{\text {th }}$ uncompensated price elasticity from Cornelsen et al. (2014), $w_{j}$ the budget share of $j$ and $\hat{\eta}_{\mathrm{i}}$ the estimated value of the $\mathrm{i}^{\text {th }}$ income elasticity. According to Approach II, the compensated price elasticities are derived from equation (1): $\tilde{\eta}_{\mathrm{ij}}^{*}=\eta_{\mathrm{ij}}+\mathrm{w}_{\mathrm{j}} \hat{\eta}_{\mathrm{i}}, \mathrm{i}, \mathrm{j}=1, \ldots, 7$. 
Table A5 Estimated uncompensated price elasticities

\begin{tabular}{|c|c|c|c|c|c|c|c|c|}
\hline $\begin{array}{c}\text { Group } \\
\text { (1) }\end{array}$ & $\begin{array}{l}\text { Fruits \& } \\
\text { vegetables } \\
\text { (2) }\end{array}$ & $\begin{array}{c}\text { Meat } \\
(3)\end{array}$ & $\begin{array}{l}\text { Fish } \\
\text { (4) }\end{array}$ & $\begin{array}{l}\text { Dairy } \\
\text { (5) }\end{array}$ & $\begin{array}{c}\text { Cereals } \\
\text { (6) }\end{array}$ & $\begin{array}{c}\text { Fats and } \\
\text { oils } \\
(7)\end{array}$ & $\begin{array}{c}\text { Sweets } \\
\text { (8) }\end{array}$ & $\begin{array}{c}\text { Non- } \\
\text { Food } \\
(9)\end{array}$ \\
\hline & \multicolumn{8}{|c|}{ A. Low Income } \\
\hline Fruits \& vegetables & -0.742 & -0.013 & -0.005 & -0.006 & -0.031 & -0.008 & -0.005 & -0.017 \\
\hline Meat & -0.022 & -0.788 & -0.006 & -0.006 & -0.034 & -0.009 & -0.005 & -0.018 \\
\hline Fish & -0.022 & -0.014 & -0.793 & -0.006 & -0.034 & -0.009 & -0.005 & -0.019 \\
\hline Dairy & -0.022 & -0.014 & -0.006 & -0.779 & -0.034 & -0.009 & -0.005 & -0.018 \\
\hline Cereals & -0.019 & -0.012 & -0.005 & -0.005 & -0.689 & -0.007 & -0.004 & -0.016 \\
\hline Fats and oils & -0.017 & -0.010 & -0.004 & -0.005 & -0.026 & -0.602 & -0.004 & -0.014 \\
\hline Sweets & -0.021 & -0.013 & -0.005 & -0.006 & -0.032 & -0.008 & -0.747 & -0.017 \\
\hline \multirow[t]{2}{*}{ Non-Food } & -0.027 & -0.017 & -0.007 & -0.008 & -0.042 & -0.011 & -0.006 & -0.990 \\
\hline & \multicolumn{8}{|c|}{ B. Medium Income } \\
\hline Fruits \& vegetables & -0.651 & -0.008 & -0.001 & -0.004 & -0.008 & -0.002 & -0.002 & 0.167 \\
\hline Meat & -0.008 & -0.717 & -0.002 & -0.004 & -0.009 & -0.002 & -0.002 & 0.185 \\
\hline Fish & -0.009 & -0.009 & -0.727 & -0.004 & -0.009 & -0.002 & -0.002 & 0.189 \\
\hline Dairy & -0.008 & -0.008 & -0.002 & -0.717 & -0.009 & -0.002 & -0.002 & 0.186 \\
\hline Cereals & -0.006 & -0.006 & -0.001 & -0.003 & -0.554 & -0.002 & -0.002 & 0.142 \\
\hline Fats and oils & -0.006 & -0.006 & -0.001 & -0.003 & -0.007 & -0.541 & -0.002 & 0.140 \\
\hline Sweets & -0.008 & -0.008 & -0.001 & -0.004 & -0.009 & -0.002 & -0.681 & 0.177 \\
\hline \multirow[t]{2}{*}{ Non-Food } & -0.017 & -0.017 & -0.003 & -0.008 & -0.018 & -0.004 & -0.005 & -1.039 \\
\hline & \multicolumn{8}{|c|}{ C. $\underline{\text { High Income }}$} \\
\hline Fruits \& vegetables & -0.530 & -0.003 & -0.001 & -0.001 & -0.003 & -0.001 & -0.001 & 0.236 \\
\hline Meat & -0.003 & -0.601 & -0.001 & -0.002 & -0.003 & -0.001 & -0.001 & 0.267 \\
\hline Fish & -0.003 & -0.003 & -0.610 & -0.002 & -0.003 & -0.001 & -0.001 & 0.272 \\
\hline Dairy & -0.003 & -0.003 & -0.001 & -0.600 & -0.003 & -0.001 & -0.001 & 0.267 \\
\hline Cereals & -0.002 & -0.002 & -0.001 & -0.001 & -0.432 & 0.000 & -0.001 & 0.192 \\
\hline Fats and oils & -0.002 & -0.002 & -0.001 & -0.001 & -0.002 & -0.420 & -0.001 & 0.188 \\
\hline Sweets & -0.003 & -0.003 & -0.001 & -0.002 & -0.003 & -0.001 & -0.561 & 0.250 \\
\hline Non-Food & -0.010 & -0.010 & -0.003 & -0.005 & -0.010 & -0.002 & -0.004 & -1.024 \\
\hline
\end{tabular}

Source: Cornelsen et al. (2014). 
Figure A1 Compensated own-price elasticities, Approach I vs. Approach II

A. Low income

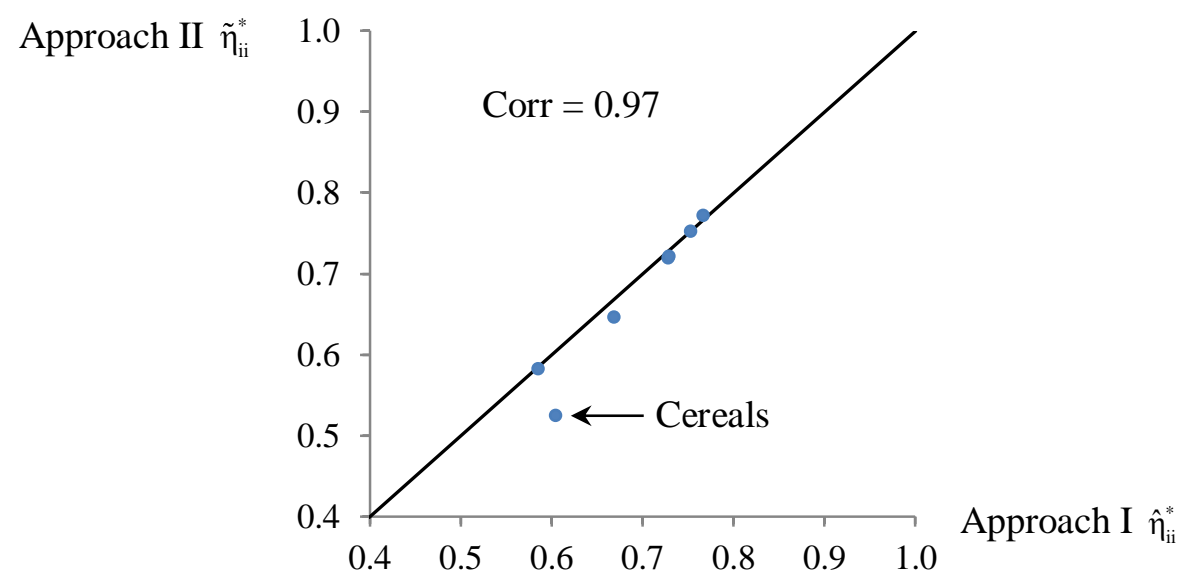

B. Medium income

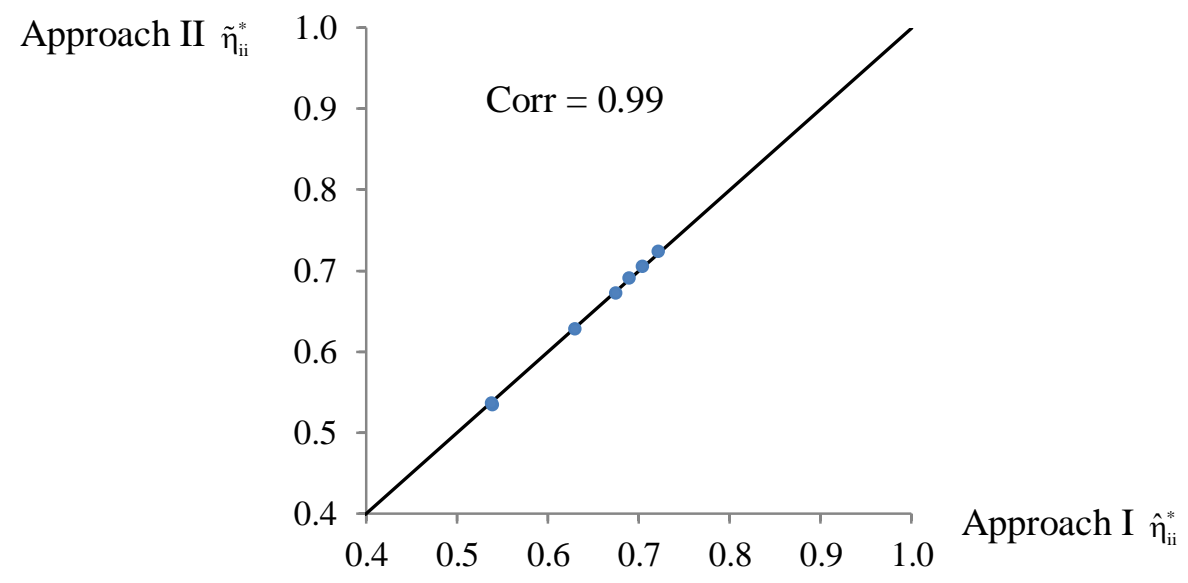

C. High income

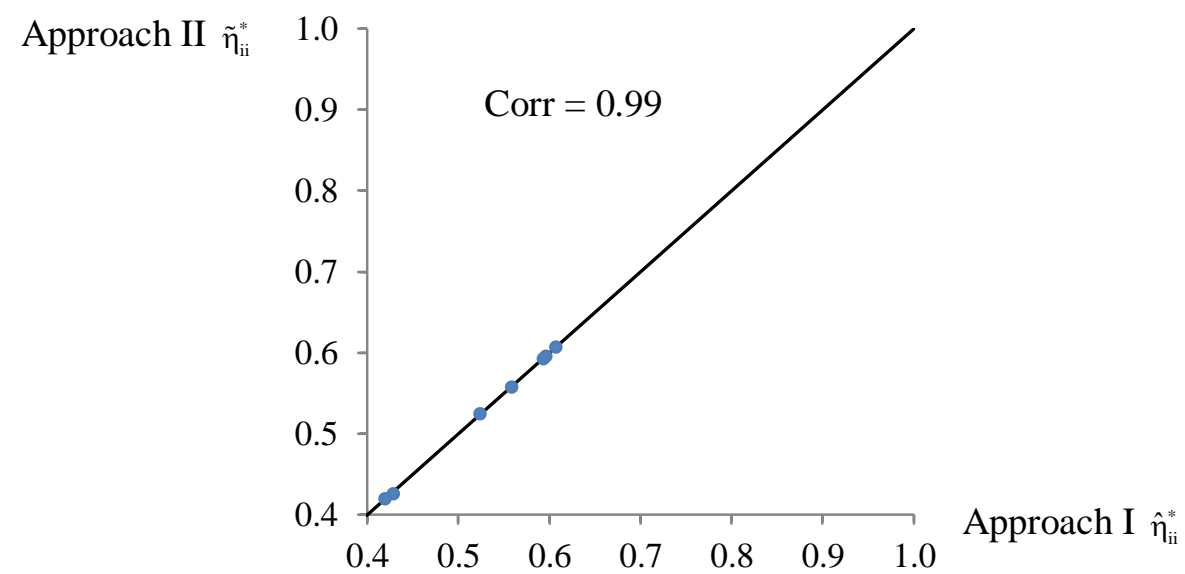

Notes: Along the solid lines, Approach I = Approach II. Approach I and II elasticities are the diagonal elements of Tables 3 and A4, respectively. 
Figure A2 Estimated and actual uncompensated own-price elasticities, Approach I

\section{A. Low income}

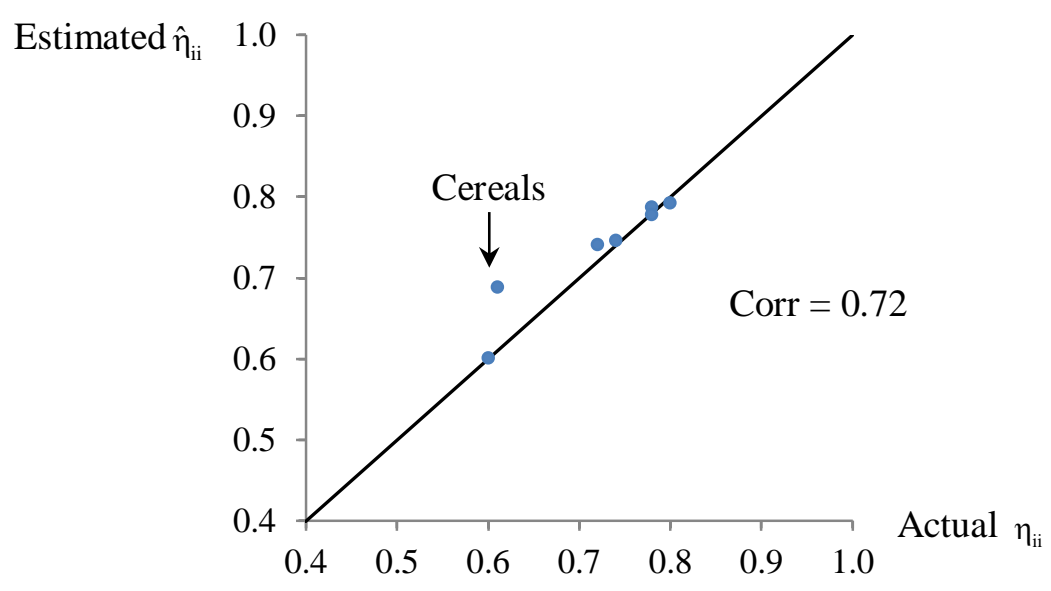

\section{B. Medium income}

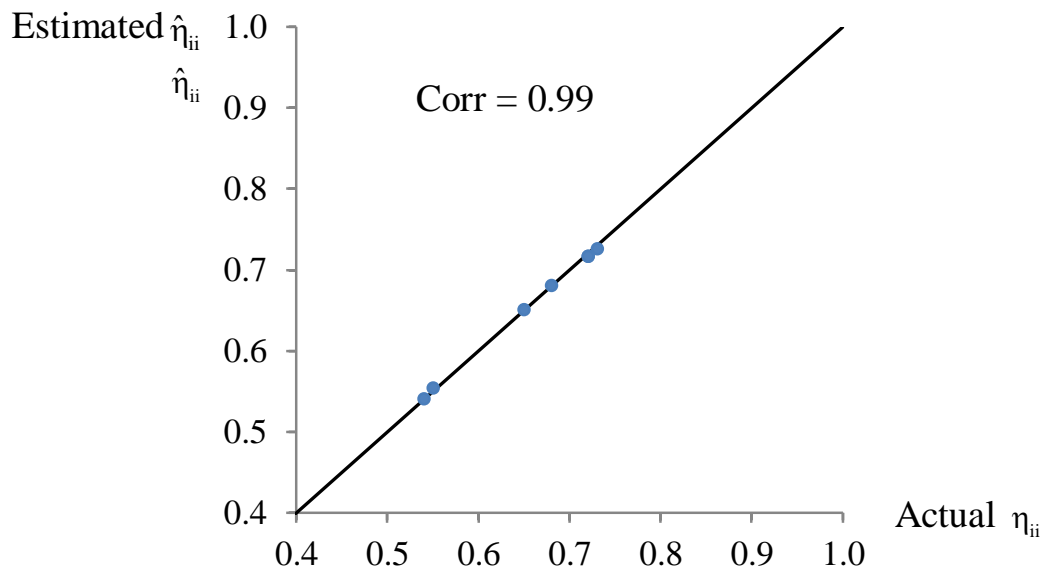

C. $\underline{\text { High income }}$

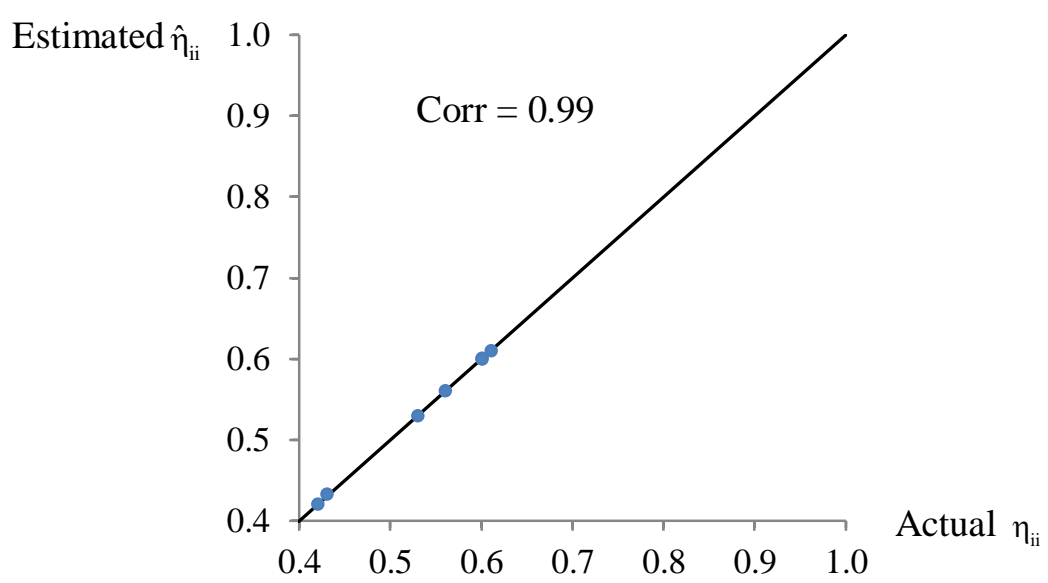

Note: Along the solid lines, estimated $=$ actual. Actual and estimated uncompensated own-price elasticities are from Table A1 and Table A5, respectively. 